$$
\begin{aligned}
& \text { اثر تنش شورى بر جوانه زنى بذر، رشف اوليه تياهك و ساختار تشريحى اندامهاى رويشى } \\
& \text { جغندرقن } \\
& \text { فاطمه نزادحبيبوش' و محمدباقر رضايى }
\end{aligned}
$$

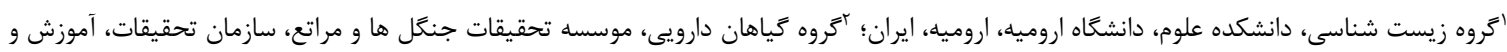

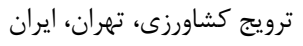

$$
\begin{aligned}
& \text { f.nejadhabibvash@urmia.ac.ir ، مسئول مكاتبات: فاطمه نزاد حبيب وشرو ترن } \\
& \text { جكيده. جغندرقند از تيره تاجخروسيان داراى نياكان شوريسند است. در اين تحقيق، اثر غلظتهاى مختلف كلريدسديم در مرحله جوانهزنى بذر كياه جغندرقند و }
\end{aligned}
$$

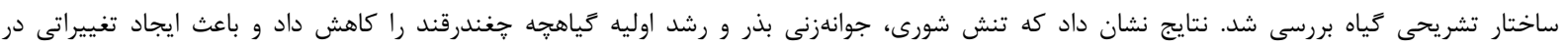

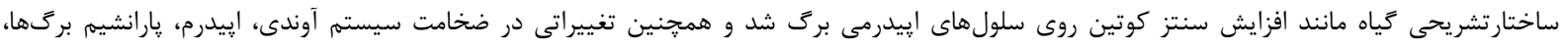

$$
\begin{aligned}
& \text { ريشها و دمبرى شد. } \\
& \text { وازه هاى كليدى. إِيدرم، برگ، پِارانشيم، ريشهجه، سرعت جوانهزنى }
\end{aligned}
$$

\title{
The effect of salinity on seed germination, early seedling growth and anatomical structure of Beta vulgaris
}

\section{Fatemeh Nejadhabibvash \& Mohammad Bagher Rezaee}

${ }^{1}$ Department of Biology, Faculty of Science, Urmia University, Urmia, Iran; ${ }^{2}$ Department of Medicinal Plants, Research Institute of Forests and Rangelands, Agricultural Research, Education and Extension Organization, Tehran, Iran

Correspondent author: Fatemeh Nejadhabibvash, f.nejadhabibvash@urmia.ac.ir

\begin{abstract}
Beta vulgaris belongs to the family Amaranthaceae and was found to have halophytic ancestors. The objective of this study was to investigate the effect of sodium chloride on seed germination, therefore the early stages of seedling growth of Beta vulgaris grown under different salinity levels $(0,100,150$ and $200 \mathrm{mM}$ of $\mathrm{NaCl})$ were studied. The experiment was laid out in a completely randomized design (CRD) with four replications. It was revealed that as concentration of $\mathrm{NaCl}$ increases, the rate and percentage of germination, length and fresh weight of radicle \& plumule and seedling vigour index decrease. In conclusion, our results indicated that salt stress decreased Beta vulgaris seed germination and early seedling growth while induced changes in the anatomical characteristics such as increased level of cutin synthesis on epidermal leaves cells and altered the thickness of vascular system, epidermis and parenchyma in leaves, roots and petioles.
\end{abstract}

Keywords. epidermis, leaf, parenchyma, radicle, rate of germination 


\section{INTRODUCTION}

Soil salinization is one of the most serious threats to irrigated crop production in arid and semi-arid regions (Zakery-Asl et al., 2014). Land affected by salinization in arid and semi-arid regions of South Asia is about 42 million hectares (FAO, 1994). At least $20 \%$ of the world's cultivated area and nearly half of the world's irrigated lands are salt- affected (Zhu, 2001). Moreover, around 33 Million hectares are in Iran, which affected nearly $55 \%$ of agricultural lands. Therefore, salinity can be hazardous to plant growth in nearly every irrigated area of Iran that is affected by the salt accumulation. Soil salinity affects plant growth due to decreasing soil osmotic potential (osmotic stress), to interfere with normal nutrient uptake, inducing ionic toxicity, and associating nutrient imbalances (An et al., 2003). Salinity also affects water availability to plants mainly through reducing the soil water potential (Hasegawa, 2013). The decrease in water availability ultimately reduces the photosynthetic rate and hence the overall growth of the plant. Processes such as seed germination, seedling growth and vigour, vegetative growth, flowering and fruit set are adversely affected by high salt concentration, ultimately causing diminished economic yield and also quality of production (Sairam and Tyagi, 2004; Zeinali et al., 2002; Zakery-Asl et al., 2014). Seed germination is usually the most critical stage in seedling establishment, determining successful crop production (Bhattacharjee, 2008). The survey of the sensitivity and tolerance level of a variety at early seedling stages for favorable crop production in a saline condition $\left({ }^{\circ} \mathrm{CHakim}\right.$ et al., 2010). Sugar beet (Beta vulgaris L.) is one of the salt tolerant crops. But it is reported to be less tolerant of salinity during germination, seedling emergence, and seedling growth stage (Jamil et al., 2006). Around 200000 ha of soils in different provinces of Iran (e.g., West and East Azarbayejan, Ardabil and Khorassan) are under sugar beet cultivation, and the effect of salinity in different stages is one of the problems in these regions. Khan et al., (2002) studied the effect of salinity and temperature on germination of Salsola iberica, they found that high salinity decreased germination rate. Katembe et al., (1998) studied the effect of salinity on germination and seedling growth of Atriplex prostrata and Atriplex patula. They suggested that the influence of $\mathrm{NaCl}$ is a combination of osmotic and ionic effects. Shahriary (2003) studied the effect of salinity stress on germination of Atriplex veruuciferum and Atriplex lentiformis; he reported high salinity inhibited Atriplex seed germination. Kamali et al. (2011) studied the germination of Prosopis juliflora and $P$. specigera under saline condition, and concluded that increasing salinity delayed germination and reduced both germination velocity and percentage. Jafari et al., (2013) surveyed the effect of salinity stress on Matricaria comomilla and Thymus deanensis seed germinations. Their results showed that high salinity caused a reduction in final germination percentage. Similarly, the negative effect of salinity on germination parameters and early seedling growth was reported by Saffan (2008), Hussein et al. (2009), Abdel-Monem et al., (2010), Yosefinia et al., (2012), Sozharajan and Natarajan (2014), Hassan et al., (2014) and Golizadeh et al., (2016). Salinity leads to anatomical modifications in plant anatomy and make them capable of minimizing the detrimental effects of salt stress. The effect of salinity on anatomical structure was discussed by Gadalla (2009) and Younis et al., (2014). Leaves and roots anatomy are affected by salt stress (Çavuşoğlu et al., 2007, 2008; Cecoli et al., 2011). High salinity mostly caused anatomical alterations such as a reduction of somata number (Çavişoğlu et al., 2007), decreased length of bundle, xylem rows, number of vessels and increased both spongy and palisade tissue (Hussein et al., 2012). El-Rodeney et al., (2012) studied the impact of different salinity levels on physiological changes and anatomical characteristics of root, stem and leaf of soybean. However, salt stressed plant showed an increase in leaf thickness in comparison to nonstressed plant (Kilic et al., 2007; Vijayan et al., 2008). Researchers found that salinity stress significantly increased cutin thickness and trichome density on epidermal cells of soybean plant (Dolatabadian et al., 2011). Peyrano et al., (1997) observed a reduction in root hydraulic conductivity in tomato under salinity. There are some studies about effect of $\mathrm{NaCl}$ salinity on germination parameters and early seedling growth of Beta vulgaris (Mohammadian, 1995; Ghoulam and Fares, 2001; Yavari et al., 2005; Dadkhah, 2007; Jafarzadeh and Aliasgharzad, 2007; Asadi Nasab et al., 2014, Khayamim et al., 2014). However, there was not previous study about effect of $\mathrm{NaCl}$ salinity on sugar beet anatomy and there were a few studies about seed germination parameters \& early seedling growth of sugar beet. Therefore, the aim of this study was to evaluate germination parameters, early seedling growth and anatomical structure of Beta vulgaris L. under different salinity conditions.

\section{MATERIALS AND METHODS Plant growth and Germination experiment}

This study was carried out in an experimental greenhouse at the Higher Education Center of Miandoab, Urmia University, Urmia, Iran. Completely randomized block design with four 
replicates was used to investigate the different levels of salinity stress tests with concentrations of 0 (control), 100, 150, 200 and $250 \mathrm{mM}$ sodium chloride, respectively. Mature, healthy and equalsized seeds were sterilized in sodium hypochlorite $10 \%(\mathrm{w} / \mathrm{v})$ for $10 \mathrm{~min}$ and rinsed several times (5-6) with sterilized deionized water according to method reported by Panuccio et al., (2014) with slight modification. The seeds were placed in $90 \mathrm{~mm}$ petri dishes on one layer of filter paper Germination was carried out in a germination chamber with a regime of $12 \mathrm{~h} \mathrm{light}$ at $25 \pm 1^{\circ} \mathrm{C}$. Distilled water or fresh salt solutions were added periodically keeping the filter paper wet during the 20 days of the experiment. Seeds were considered germinated when radicle had extended at least $2 \mathrm{~mm}$ (Redondo-Gómez et al., 2007). The length of both radicle and plumules, dry and fresh weight of both plumule and radicle were daily measured. Weight of radicle and plumule was calculated by digital scale with an accuracy of 0.001 g. Lenght of radicle and plumule was measured by a ruler.

Seeds were germinated in pots, $20 \mathrm{~cm}$ in diameter and $30 \mathrm{~cm}$ height, filled with sterile sand (previously rinsed with distilled water) and peat at 2:1 ratio, respectively. After emergence of the first true leaves, 15 days after germination, the numbers of plants were adjusted to six per pot and they were irrigated from the top with $300 \mathrm{ml}$ of distilled water every other day. The pots (five plants) were arranged in a simple randomized design and each one was considered as one replicate with three pots per treatment. At 20 days after germination, a half strength Hoagland's nutrient solution was given once a week. Then, one month after sowing, five $\mathrm{NaCl}$ concentrations; 0 (control), 100, 150, 200 and $250 \mathrm{mM}$ were applied. To avoid osmotic shock, $\mathrm{NaCl}$ concentrations were increased gradually by 50 $\mathrm{mM}$ every 2 days until the desired concentration. After 60 days of salt treatment, leaf, stem, root and petiole samples were harvested from control and $\mathrm{NaCl}$-treated plants for evaluation of various parameters.

Germination percentage (GP), germination rate (GR) and seedling vigour index (SVI) for each treatment was calculated according to the following formula:

$\mathrm{GP}=(\mathrm{NG} / \mathrm{NT}) * 100 . \quad$ In the formula, $\mathrm{GP}=$ germination percentage, $\mathrm{NG}=$ number of seeds germinated, NT=Total number of planted seeds (Kandil et al., 2012).

$(G R)-\sum_{i=}^{n} \frac{S i}{D i}$ in which, GR=germination rate

(number of seed per day), $\mathrm{Si}=$ number of germinated seeds in each count, and $\mathrm{Di}=$ days to count, may days in which germinated seeds (Kader \& Jutzi,
2004). Seedling Vigour Index (SVI) was calculated following a modified formula of Abdul-Baki and Anderson (1973). SVI $=$ Germination percentage $\times$ seedling length.

\section{Anatomical study experiment:}

For anatomical studies, fresh samples of leaf, root and petiole were used in each case for experimental analyses and measurements. Anatomical studies were performed using an average four fresh specimens kept in glycerin and alcohol 96\% (1:1). Free hand sections of leaves, roots and petioles were stained with Carmine - Methyl green. Slides were viewed and photographed with light microscope model BX40 Olympus. Measurements of various cells and tissues were taken with ocular micrometer.

\section{Statistical analysis}

The obtained data were analyzed using the statistical program SPSS (version 21.0). Analysis of variance was performed using one-way analysis of variance (ANOVA) at 5 percent probability level. The comparison of means by using Duncan's multiple range tests was performed.

\section{RESULTS AND DISSCUSION Effects of $\mathrm{NaCl}$ treatments on seed germination}

The germination percentage of untreated seeds (control) was $58 \%$ while the germination percentage in seeds exposed to $100,150,200$ and $250 \mathrm{mM}$ $\mathrm{NaCl}$ treatments were $24,9,0$ and $0 \%$, respectively. The germination rate index of the control seeds was 0.54 while those in seeds exposed to $100,150,200$ and $250 \mathrm{mM} \mathrm{NaCl}$ treatments were $0.28,0.08,0$ and $0 \mathrm{no}^{-1}$ day, respectively (Table 1 ). The highest seed germination percentage and rate related to $100 \mathrm{~mm}$ $\mathrm{NaCl}$ concentration ( $24.44 \%$ and $0.28 \mathrm{no}^{-1}$ days) and the lowest ones corresponded to 200 and $250 \mathrm{mM}$ $\mathrm{NaCl}$ concentration $\left(0 \%\right.$ and $0 \mathrm{no}^{-1}$ day).

Salinity had highly significant effect on growth attributes of Beta vulgaris L. in petri dishes under different levels of $\mathrm{NaCl}$ stress. In general, our results showed that the percentage and rate of germination in all $\mathrm{NaCl}$ concentrations statistically reduced (Table 1). The highest percentage and rate of germination was noted at $100 \mathrm{mM} \mathrm{NaCl}$ concentration ( $2.4 \%$ and 0.28 no $^{-1}$ day, respectively). The lowest percentage and rate of germination corresponded to $250 \mathrm{mM} \mathrm{NaCl}$ treatment $(0 \%$ and 0 no ${ }^{-1}$ day, respectively) (Table 1 ). Comparision of means with Duncan test showed significant difference among $\mathrm{NaCl}$ treatments (Table 1).

Among the stages of the plant life cycle, seed germination and seedling emergence and establishment are key processes in the survival and growth of plant (Hadas, 2004). It is well established 
that salt stress has negative correlation with seed germination and vigour (Rahman et al., 1996).

Researchers suggested that a decrease in germination is related to salinity-induced disturbance of metabolic process leading to increase in phenolic compounds (Ayaz et al., 2000). It is postulated that germination rate and the final seed germination decrease with the decline of the water movement into the seeds during imbibitions (Hadas, 1977). Salt induced inhibition of seed germination could be associated to osmotic stress or to specific ion toxicity (Huang et al., 1995). Decrease and delay in germination in saline medium was also reported by these results are similar in line with Francois et al., 1984; Francois, 1985; Mauromicale et al., 2002; Rahman et al., 2000; Gulzar et al., 2001; Jeannette et al., 2002; Hagghani et al., 2008. These researchers observed decrease in percentage germination and seedling emergence with enhanced salinity.

Effect of $\mathrm{NaCl}$ on Plumule and Radicle length:

The results showed that plumule and radicle lengths decreased with the increase in $\mathrm{NaCl}$ concentrations (Table 1). The highest plumule length was observed at control and $100 \mathrm{mM} \mathrm{NaCl}$ treatments (58 and $2.93 \mathrm{~mm}$, respectively). The maximum reduction in plumule length was observed in 200 and $250 \mathrm{mM} \mathrm{NaCl}$ treatments (Table 1). The highest and lowest radicle lenght was noted in 100, 200 and $250 \mathrm{mM}$ (2.6, 0 and $0 \mathrm{~mm}$, respectively) (Table 1). Plumule length was not affected by 100 and $150 \mathrm{mM}$, also 200 and $250 \mathrm{NaCl}$ concentrations (Table 1) so that there was not significant difference between those treatments.

Abiotic stresses are reported to alter levels of plant growth hormones leading to decrease in plant growth (Gupta et al., 1993). The shoot and root length are the highly important characters for salt stress because roots are in direct contact with soil and absorb water from soil and shoot provide it to the rest of the plant. For this reason, root and shoot length provides an important clue to the reaction of plants to salt stress (Jamil, 2004). In this study, high salinity inhibited plumule and radical elongation of Beta vulgaris. This was consistent with the findings of Munns and Termaat (1986) who state that the growth of a plant is generally reduced by salinity. Sativa and Jakhar (2015) showed that plumule and radicle length of Cicer arietinum $\mathrm{L}$. were significantly reduced by increasing salinity. Xiong and Zhu (2002) attributed that salt stress inhibited the efectiveness of translocation and assimilation of stored materials and might have caused a decline in shoot growth. The reduction in root and shoot development may be due to toxic effects of the $\mathrm{NaCl}$ used further more unbalanced nutrient uptake by the seedlings. Ability of a root system to control entry of ions to the shoot is crucial importance to plant survival in the presence of $\mathrm{NaCl}$ (Hajibagheri et al., 1989). Root elongation may be inhibited by high salinity due to slowing down the uptake of water by the plants (Werner et al., 1995).

\section{Effect of $\mathrm{NaCl}$ on Plumule and Radicle fresh weight:}

Our results showed that fresh weight of both radicle and plumule of Beta vulgaris statistically decreased with the increase in $\mathrm{NaCl}$ concentrations (Table 1). The highest plumule and radicle fresh weight corresponded to $100 \mathrm{mM} \mathrm{NaCl}$ concentration (0.014 and $0.004 \mathrm{mg}$, respectively). The lowest fresh weight of radicle and plumule corresponded to 200 and $250 \mathrm{mM} \mathrm{NaCl}$ concentration $(0$ and $0 \mathrm{mg}$, respectively) (Table 1). Plumule and radicle fresh weights in seedling treated with $\mathrm{NaCl}$ concentrations became smaller than control group but, not significant differences were found between two groups (seedlings treated with $100 \& 150 \mathrm{mM}$ and $200 \& 250 \mathrm{mM} \mathrm{NaCl}$ concentrations) (Table 1). Also, treatments of seedlings with 150, 200 and 250 $\mathrm{mM} \mathrm{NaCl}$ concentrations had no significant effect on radicle fresh weight (Table 1).

During imbibition, movement of water occurs through aquaporins, which have reduced expression in the presence of salt (Boursiac et al., 2005). Studies have shown that $\mathrm{NaCl}$ treatment decreased some growth parameters such as fresh weight of root of plants (Yildirim et al., 2008). Accordingly, Mori et al., (2011) reported that salinity decreased the plumule fresh weight of plants.

\section{Effect of $\mathrm{NaCl}$ on Radicle and Plumule dry weight:}

Our results showed that dry weight of both radicle and plumule statistically decreased with salt increaese (Table 1). The highest weight of plumule and radicle corresponded to $100 \mathrm{mM} \mathrm{NaCl}$ concentration ( 0.005 and $0.05 \mathrm{mg}$, respectively). The lowest amount of dry weight of radicle and plumule corresponded to 200 and $250 \mathrm{mM}$ concentrations of sodium chloride $(0$ and $0 \mathrm{mg}$, respectively) (Table 1). Plumule and radicle dry weights were affected by $\mathrm{NaCl}$ treatments, showing a decrease in comparison with the control group. Also, our results were in agreement with those obtained by other resrarchers (Redmann and Belyk, 1994; Osorio et al., 1998; EL-Melegi et al., 2004; François and Bahizire, 2007; Bahrami et al., 2012; Asadi Nasab, 2014).

As salinity levels increased, both fresh weight and dry matter of seedlings declined. Salt stress causes ionic imbalance (Zhu et al., 1997), with excess sodium and chloride ions having a deleterious effect on many cellular systems (Serrano et al., 1999), 
therefore plant survival and growth depends on adaptations to re-establish homeostasis. High salinity also inflicts hyper osmotic shock on plants, as chemical activity of water is decreased, causing a loss of cell turgor. Salt induced reduction in chloroplast stromal volume and generation of reactive oxygen species (ROS) also plays an important role in decreasing plant photosynthetic capacity and therefore growth (Price and Hendry, 1991).

\section{Seedling vigour Index}

Seedling vigour test was made on seeds produced from plants grown under varied levels of salinity. The results revealed significant difference in seedling vigor between seeds produced from control and saline grown plant except for $100 \mathrm{mM} \mathrm{NaCl}$ treatments (Table 1). The reduction gets stronger particularly at the higher levels of $\mathrm{NaCl}$ concentration $(150 \mathrm{mM})$.

Seedling vigour is evaluated in terms of germination percentage and seedling length and has direct relationships with both parameters. Low seedling vigour might affect the plant yield in two ways: first, percentage of emerged seedlings in the field is less than expected, and consequently, plant density falls below the desired level, and second, the growth rate of seedling in such plants might be lower than the growth rate of plants produced from strong seeds (Roberts \& Osei-Bonsu, 1988). Seedling vigour index and $\mathrm{NaCl}$ concentration were negatively correlated. Generally, the increase in salt concentration decreased the seedling vigour index of Beta vulgaris and this was in line with the findings of Khodarampour et al. (2011), Mensuh et al., (2006) and Mostafavi (2011).

\section{Anatomical structures}

Cross section of leaf, root and petiole of Beta vulgaris were analyzed to assess the effects of various salt concentrations to the anatomical adaptations of this plant to be under external salinity (Figs. 1-3). There was a significant alteration in anatomical feautures of leaf, root and petiole of Beta vulgaris plants imposed to various levels of salinity (Tables 2, 3, 4).

The statistical analysis confirmed that the increase in $\mathrm{NaCl}$ concentration; significant changes were noticed in root anatomical characteristics (Table 2). By examining the transverse sections of root from control and treated samples, it was observed that the thickness of epidermal layer was increased in $\mathrm{NaCl}$-treated plants as compared to control group. Results showed that the thickest epidermal layer was observed in $200 \quad(49.96$ $\mu \mathrm{m})$ and $250 \mathrm{mM} \mathrm{NaCl}$ concentrations (49.96 $\mu \mathrm{m})$ (Table 2). The highest phloem thickness was observed in $100 \mathrm{mM} \mathrm{NaCl}$ concentration $(200.03 \mu \mathrm{m})$. Xylem tissue thickness of the root reached the maximum $(190.03 \mu \mathrm{m})$ in treated plants with $100 \mathrm{mM} \mathrm{NaCl}$ as compared to control group and then decreased at higher salinity. Cortical paranchyma became thicker in $100 \mathrm{mM} \mathrm{NaCl}$ concentration $(400.03 \mu \mathrm{m})$. The protoxylem and metaxylem diameter became bigger than the control in $100 \mathrm{mM}$ $\mathrm{NaCl}$ concentration $(40.03$ and $60.33 \mu \mathrm{m}$, respectively) (Table 2). The lowest epidermal layer thickness was noticed at $100 \mathrm{mM} \mathrm{NaCl}$ concentration $(30.03 \mu \mathrm{m}) \quad$ (Table 2). The mimimum thickness of phloem, xylem, cortical paranchyma \& protoxylem and metaxylem diameter was observed in $250 \mathrm{mM} \mathrm{NaCl}$ concentration $(100.33,150.00,179.96,18.33$ and $25.00 \mu \mathrm{m}$, respectively (Table 2).

Table 1. The effect of salinity on seed germination characteristics and early seedling growth of Beta vulgaris.

\begin{tabular}{|c|c|c|c|c|c|c|}
\hline $\begin{array}{l}\text { Germination } \\
\text { measurments }\end{array}$ & $250(\mathrm{mM})$ & $200(\mathrm{mM})$ & $150(\mathrm{mM})$ & $100(\mathrm{mM})$ & $\begin{array}{c}\text { Control } \\
\text { (No NaCl) }\end{array}$ & $\mathrm{F}$ \\
\hline $\begin{array}{l}\text { Germination } \\
\text { percent }\end{array}$ & $0.00 \pm 0.00^{\mathrm{c}}$ & $0.00 \pm 0.00^{\mathrm{c}}$ & $8.88 \pm 0.84^{\mathrm{bc}}$ & $24.44 \pm 0.69^{b}$ & $57.776 \pm 0.77^{\mathrm{a}}$ & $15.71^{*}$ \\
\hline Germination rate & $0.00 \pm 0.00^{\mathrm{c}}$ & $0.00 \pm 0.00^{\mathrm{c}}$ & $0.081 \pm 0.03^{\mathrm{c}}$ & $0.288 \pm 0.07^{\mathrm{b}}$ & $0.5413 \pm 0.15^{\mathrm{a}}$ & $24.81^{*}$ \\
\hline $\begin{array}{l}\text { Seedling vigour } \\
\text { index }\end{array}$ & $0.00 \pm 0.00^{\mathrm{b}}$ & $0.00 \pm 0.00^{\mathrm{b}}$ & $35.53 \pm 0.00^{\mathrm{b}}$ & $134.216 \pm 0.00^{\mathrm{a}}$ & $752 / 208 \pm 0.00^{\mathrm{a}}$ & $45.36^{*}$ \\
\hline Plumule length & $0.00 \pm 0.00^{\mathrm{c}}$ & $0.00 \pm 0.00^{\mathrm{c}}$ & $2.700 \pm 0.05^{\mathrm{b}}$ & $2.93 \pm 0.50^{\mathrm{b}}$ & $5.800 \pm 0.60^{\mathrm{a}}$ & $50.31 *$ \\
\hline Radicle length & $0.00 \pm 0.00^{\mathrm{d}}$ & $0.00 \pm 0.00^{\mathrm{d}}$ & $1.07 \pm 0.11^{\mathrm{c}}$ & $2.60 \pm 0.26^{\mathrm{b}}$ & $7.370 \pm 0.06^{\mathrm{a}}$ & $110.22 *$ \\
\hline $\begin{array}{c}\text { Plumule fresh } \\
\text { weight }\end{array}$ & $0.00 \pm 0.00^{\mathrm{c}}$ & $0.00 \pm 0.00^{\mathrm{c}}$ & $0.011 \pm 0.00^{\mathrm{b}}$ & $0.014 \pm 0.00^{\mathrm{b}}$ & $0.033 \pm 0.00^{\mathrm{a}}$ & $40.80^{*}$ \\
\hline $\begin{array}{l}\text { Radicle fresh } \\
\text { weight }\end{array}$ & $0.00 \pm 0.00^{\mathrm{b}}$ & $0.00 \pm 0.00^{\mathrm{b}}$ & $0.002 \pm 0.00^{\mathrm{b}}$ & $0.004 \pm 0.00^{\mathrm{ab}}$ & $0.007 \pm 0.00^{\mathrm{a}}$ & $3.50 *$ \\
\hline Plumule dry weight & $0.00 \pm 0.00^{\mathrm{d}}$ & $0.00 \pm 0.00^{\mathrm{d}}$ & $0.001 \pm 0.00^{\mathrm{c}}$ & $0.005 \pm 0.00^{\mathrm{b}}$ & $0.006 \pm 0.00^{\mathrm{a}}$ & $225.50^{*}$ \\
\hline Radicle dry weight & $0.00 \pm 0.00^{\mathrm{d}}$ & $0.00 \pm 0.00^{\mathrm{d}}$ & $0.004 \pm 0.00^{\mathrm{c}}$ & $0.005 \pm 0.00^{\mathrm{b}}$ & $0.008 \pm 0.00^{\mathrm{a}}$ & $213.00^{*}$ \\
\hline
\end{tabular}


Table 2. The effect of salinity on root anatomical parameters of Beta vulgaris L.

\begin{tabular}{ccccccc}
\hline $\begin{array}{c}\text { NaCl } \\
\begin{array}{c}\text { oncentration } \\
(\mathrm{mM})\end{array}\end{array}$ & $\begin{array}{c}\text { Metaxylem } \\
\text { Vessel Diameter } \\
(\mu \mathrm{m})(\end{array}$ & $\begin{array}{c}\text { Protoxylem } \\
\text { Vessel Diameter } \\
(\mu \mathrm{m})\end{array}$ & $\begin{array}{c}\text { Paranchyma } \\
(\mu \mathrm{m})\end{array}$ & $\begin{array}{c}\text { Xylem Tissue } \\
\text { Thickness }(\mu \mathrm{m})\end{array}$ & $\begin{array}{c}\text { Phloem Tissue } \\
\text { Thickness }(\mu \mathrm{m})\end{array}$ & $\begin{array}{c}\text { Epiderm } \\
\text { Thickness } \\
(\mu \mathrm{m})\end{array}$ \\
\hline control & $80.033 \pm 0.03^{\mathrm{a}}$ & $60.033 \pm 0.05^{\mathrm{a}}$ & $586.633 \pm 0.05^{\mathrm{a}}$ & $200.033 \pm 0.05^{\mathrm{a}}$ & $200.033 \pm 0.05^{\mathrm{a}}$ & $30.033 \pm 0.06^{\mathrm{a}}$ \\
100 & $60.033 \pm 0.05^{\mathrm{b}}$ & $40.033 \pm 0.04^{\mathrm{b}}$ & $400.033 \pm 0.05^{\mathrm{b}}$ & $190.033 \pm 0.06^{\mathrm{b}}$ & $200.033 \pm 0.01^{\mathrm{a}}$ & $30.03 \pm 0.05^{\mathrm{b}}$ \\
150 & $49.996 \pm 0.08^{\mathrm{c}}$ & $30.033 \pm 0.07^{\mathrm{c}}$ & $300.033 \pm 0.04^{\mathrm{c}}$ & $169.033 \pm 0.05^{\mathrm{c}}$ & $110.033 \pm 0.05^{\mathrm{b}}$ & $39.96 \pm 0.08^{\mathrm{b}}$ \\
200 & $30.033 \pm 0.03^{\mathrm{d}}$ & $25.033 \pm 0.05^{\mathrm{d}}$ & $200.033 \pm 0.04^{\mathrm{d}}$ & $170.033 \pm 0.05^{\mathrm{c}}$ & $100.033 \pm 0.03^{\mathrm{b}}$ & $49.96 \pm 0.08^{\mathrm{c}}$ \\
250 & $30.033 \pm 0.05^{\mathrm{d}}$ & $18.033 \pm 0.05^{\mathrm{e}}$ & $179.96 \pm 0.09^{\mathrm{e}}$ & $150.033 \pm 0.03^{\mathrm{d}}$ & $100.033 \pm 0.05^{\mathrm{c}}$ & $49.96 \pm 0.05^{\mathrm{c}}$ \\
\hline ANOVA & $405000.80^{*}$ & $239220.00^{*}$ & $342170.80^{*}$ & $102.00^{*}$ & $253752.200^{*}$ & $89401.200^{*}$ \\
\hline
\end{tabular}

The values are mean \pm SD $(n=4)$. *: significant at $\mathrm{p}<0.05$, Means followed by different letters are significantly different at $\mathrm{p}<.05$.

Table 3. The effect of salinity on petiole anatomical parameters of Beta vulgaris L.

\begin{tabular}{cccccccc}
\hline $\begin{array}{c}\mathrm{NaCl} \\
\begin{array}{c}\text { Concentration } \\
(\mathrm{mM})\end{array}\end{array}$ & $\begin{array}{c}\text { Protoxylem } \\
\text { Vessel } \\
\text { Diameter } \\
(\mu \mathrm{m})\end{array}$ & $\begin{array}{c}\text { Metaxylem } \\
\text { Diameter } \\
(\mu \mathrm{m})\end{array}$ & $\begin{array}{c}\text { Xylem Tissue } \\
\text { Thickness } \\
(\mu \mathrm{m})\end{array}$ & $\begin{array}{c}\text { Phloem } \\
\text { Tissue } \\
\text { Thickness } \\
(\mu \mathrm{m})\end{array}$ & $\begin{array}{c}\text { Paranchyma } \\
\text { Thickness } \\
(\mu \mathrm{m})\end{array}$ & $\begin{array}{c}\text { Epiderm } \\
\text { Thickness } \\
(\mu \mathrm{m})\end{array}$ & $\begin{array}{c}\text { Cuticle } \\
\text { Thickness } \\
(\mu \mathrm{m})\end{array}$ \\
\hline control & $25.33 \pm 0.70^{\mathrm{a}}$ & $45.333 \pm 0.30^{\mathrm{a}}$ & $130.33 \pm 0.30^{\mathrm{a}}$ & $100.033 \pm 0.57^{\mathrm{a}}$ & $350.00 \pm 0.28^{\mathrm{a}}$ & $40.0 \pm 0.100^{\mathrm{a}}$ & $1.00 \pm 0.00^{\mathrm{a}}$ \\
100 & $22.33 \pm 0.57^{\mathrm{b}}$ & $37.33 \pm 0.40^{\mathrm{b}}$ & $110.00 \pm 0.00^{\mathrm{b}}$ & $90.33 \pm 0.89^{\mathrm{b}}$ & $299.66 \pm 0.57^{\mathrm{b}}$ & $35.0 \pm 0.100^{\mathrm{b}}$ & $1.00 \pm 0.00^{\mathrm{a}}$ \\
150 & $18.66 \pm 0.20^{\mathrm{c}}$ & $30.00 \pm 0.00^{\mathrm{c}}$ & $90.33 \pm 0.57^{\mathrm{c}}$ & $80.33 \pm 0.57^{\mathrm{c}}$ & $250.00 \pm 1.00^{\mathrm{c}}$ & $29.96 \pm 0.00^{\mathrm{c}}$ & $1.00 \pm 0.00 \mathrm{a}$ \\
200 & $14.66 \pm 0.50^{\mathrm{d}}$ & $25.66 \pm 0.90^{\mathrm{d}}$ & $80.333 \pm 0.43^{\mathrm{d}}$ & $75.333 \pm 0.57^{\mathrm{d}}$ & $230.00 \pm 0.60^{\mathrm{d}}$ & $20.0 \pm 0.30^{\mathrm{d}}$ & $1.00 \pm 0.00^{\mathrm{a}}$ \\
250 & $11.66 \pm 0.60^{\mathrm{e}}$ & $25.66 \pm 0.57^{\mathrm{d}}$ & $70.333 \pm 0.50^{\mathrm{e}}$ & $65.00 \pm 0.00^{\mathrm{e}}$ & $200.33 \pm 0.57^{\mathrm{e}}$ & $19.99 \pm 0.03^{\mathrm{d}}$ & $1.00 \pm 0.00^{\mathrm{a}}$ \\
\hline ANOVA & $807.875^{*}$ & $276.300^{*}$ & $6499.000^{*}$ & $2085.250^{*}$ & $8768.52^{*}$ & $32781.95^{*}$ & $0.000^{*}$ \\
\hline The values are mean $\pm \mathrm{SD}(\mathrm{n}=4) *$ significant at $\mathrm{p}<0.05$, Means followed by different letters are significantly different at $\mathrm{p}<0.05$
\end{tabular}

Table 4. The effects of salinity on leaf anatomical parameters of Beta vulgaris L.

\begin{tabular}{cccccc}
\hline $\begin{array}{c}\text { NaCl } \\
\begin{array}{c}\text { Concentration } \\
(\mathrm{mM})\end{array}\end{array}$ & $\begin{array}{c}\text { Total Leaf } \\
\text { Thickness }(\mu \mathrm{m})\end{array}$ & $\begin{array}{c}\text { Mesophyll } \\
\text { Thickness }(\mu \mathrm{m})\end{array}$ & $\begin{array}{c}\text { Lower } \\
\text { Epiderm } \\
\text { Thickness } \\
(\mu \mathrm{m})\end{array}$ & $\begin{array}{c}\text { Upper } \\
\text { Epiderm } \\
\text { Thickness } \\
(\mu \mathrm{m})\end{array}$ & $\begin{array}{c}\text { Cuticle } \\
\text { Thickness } \\
(\mu \mathrm{m})\end{array}$ \\
\hline control & $839.996 \pm 0.06^{\mathrm{e}}$ & $760.033 \pm 0.04^{\mathrm{a}}$ & $58.033 \pm 0.05^{\mathrm{a}}$ & $60.033 \pm 0.08^{\mathrm{a}}$ & $10.033 \pm 0.00^{\mathrm{e}}$ \\
100 & $809.966 \pm 0.05^{\mathrm{d}}$ & $730.033 \pm 0.05^{\mathrm{b}}$ & $49.033 \pm 0.05^{\mathrm{b}}$ & $55.033 \pm 0.09^{\mathrm{b}}$ & $11.033 \pm 0.03^{\mathrm{d}}$ \\
150 & $800.033 \pm 0.06^{\mathrm{c}}$ & $710.033 \pm 0.03^{\mathrm{c}}$ & $40.033 \pm 0.09^{\mathrm{c}}$ & $45.033 \pm 0.06^{\mathrm{c}}$ & $15.033 \pm 0.04^{\mathrm{c}}$ \\
200 & $729.966 \pm 0.06^{\mathrm{b}}$ & $630.000 \pm 0.05^{\mathrm{e}}$ & $32.966 \pm 0.05^{\mathrm{d}}$ & $38.033 \pm 0.05^{\mathrm{d}}$ & $18.033 \pm 0.05^{\mathrm{b}}$ \\
250 & $670.032 \pm 0.03^{\mathrm{a}}$ & $560.033 \pm 0.05^{\mathrm{d}}$ & $25.966 \pm 0.05^{\mathrm{e}}$ & $30.033 \pm 0.05^{\mathrm{e}}$ & $22.033 \pm 0.07^{\mathrm{a}}$ \\
ANOVA & $4272901.20^{*}$ & $95157180.25^{*}$ & $155430.00^{*}$ & $134370.00^{*}$ & $27885.25^{*}$ \\
\hline
\end{tabular}

The values are mean $\pm \mathrm{SD},(\mathrm{n}=4)$. ${ }^{*}$ significant at $\mathrm{p}<0.05$, Means followed by different letters are significantly different at $\mathrm{p}<$ 0.05 .

On the contrary, cross-sectional thickness of the petiole epiderm, paranchyma, phloem, xylem and metaxylem \& protoxylem vessel diameter showed significant differences between all treatments (Table 3) decreasing from control to high $\mathrm{NaCl}$ concentration. There was no significant difference between two treatments $(200$ and $250 \mathrm{mM} \mathrm{NaCl}$ concentration) on epidermis thickness and metaxylem vessel diameter (Table 3). On regard to cuticle, all of the salinity treatments were not significantly different than the control. The highest and the lowest epidermis, paranchyma, phloem, xylem thickness and metaxylem \& protoxylem vessel diameter were related to control and $250 \mathrm{mM}$ $\mathrm{NaCl}$ treatment, respectively (Table 3 ).

Higher $\mathrm{NaCl}$ concentration $(250 \mathrm{mM})$ induced increase the number of subsidiary vascular bundles of Beta vulgaris petiole (Fig. 2). There were 3 subsidiary vascular bundles and three main vascular bundles in petiole of control, $100 \mathrm{mM}, 150 \mathrm{mM}$ and $200 \mathrm{mM} \mathrm{NaCl}$ concentration treatment plants but at higher concentration level $(250 \mathrm{mM})$ the number of subsidiary bundles was increased (up to 6 vascular bundles). Also, the petiole shape was different between control and salinity stressed plants (Fig. 2).

Results of leaf anatomical studies showed that salinity had noticeable effect on leaf structure of Beta vulgaris L. (Table 4, Fig. 3). Also, the statistical analysis showed that with increasing in $\mathrm{NaCl}$ concentration, significant changes were observed in leaf anatomical characteristics (Table 4). Results showed that the highest cuticle thickness was observed in $250 \mathrm{mM} \mathrm{NaCl}$ concentration (22.03 $\mu \mathrm{m})$ while the lowest one was observed in $100 \mathrm{mM}$ $\mathrm{NaCl}$ concentration $(11.03 \mu \mathrm{m})$ (Table 4). The highest upper and lower epidermis, mesophyll and total leaf thickness was observed in $100 \mathrm{mM} \mathrm{NaCl}$ concentration (lowest $\mathrm{NaCl}$ level) $(55.03,49.03$, 73.03 and $80.03 \mu \mathrm{m}$, respectively) (Table 3 ). The lowest upper and lower epidermis, mesophyll and total leaf thickness was observed in $250 \mathrm{mM} \mathrm{NaCl}$ concentration $(30.03,25.96,560.03$ and 670.0303 $\mu \mathrm{m}$, respectively) (Table 4 ). 


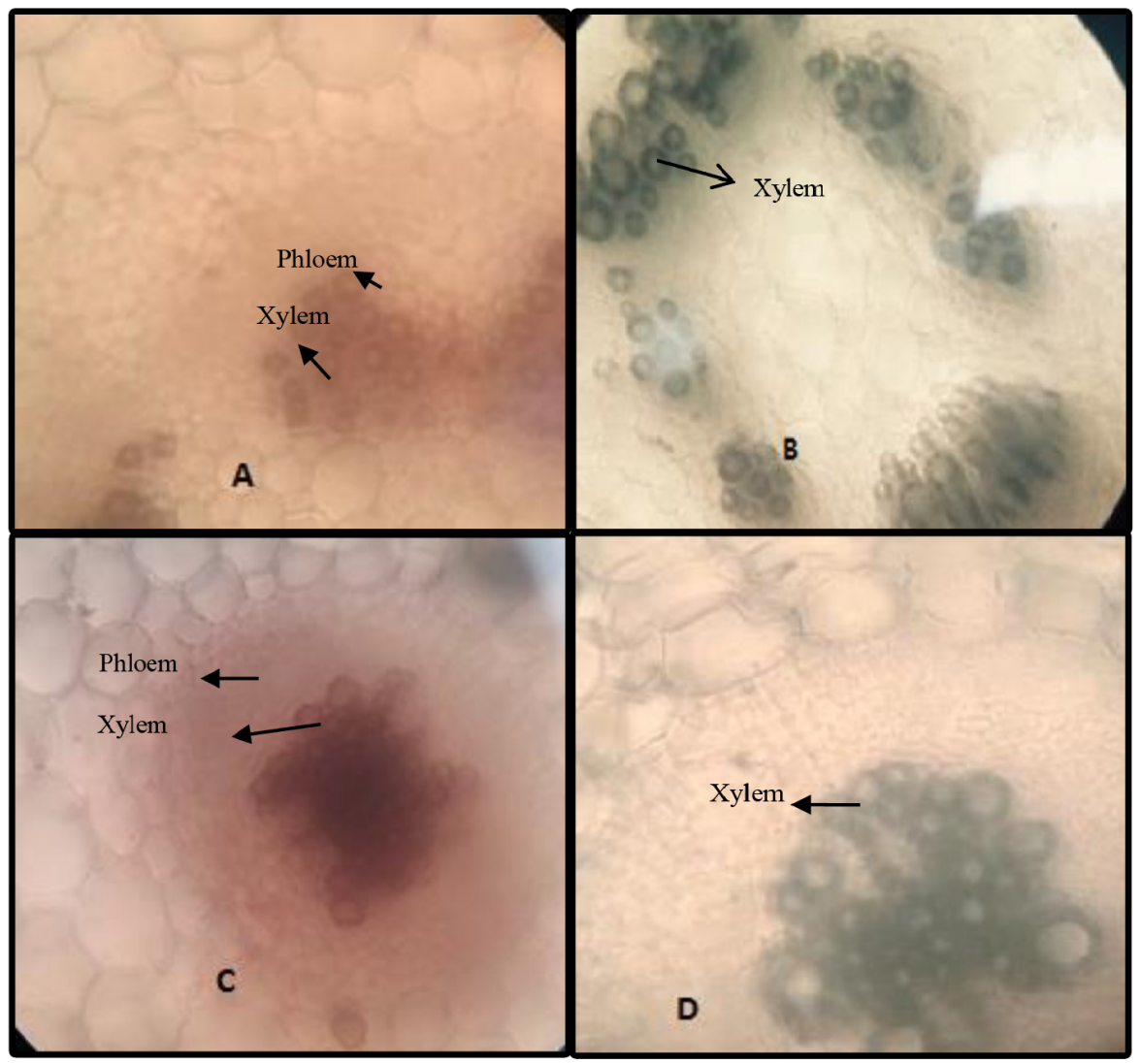

Figure 1. The effect of salinity on the root anatomy of Beta vulgaris L. plants treated with various levels of salinity. A. control (×40), B. $150 \mathrm{mM} \mathrm{NaCl}(\times 40)$, C. $250 \mathrm{mM} \mathrm{NaCl}(\times 40)$, D. $200 \mathrm{mM} \mathrm{NaCl}(\times 40)$.

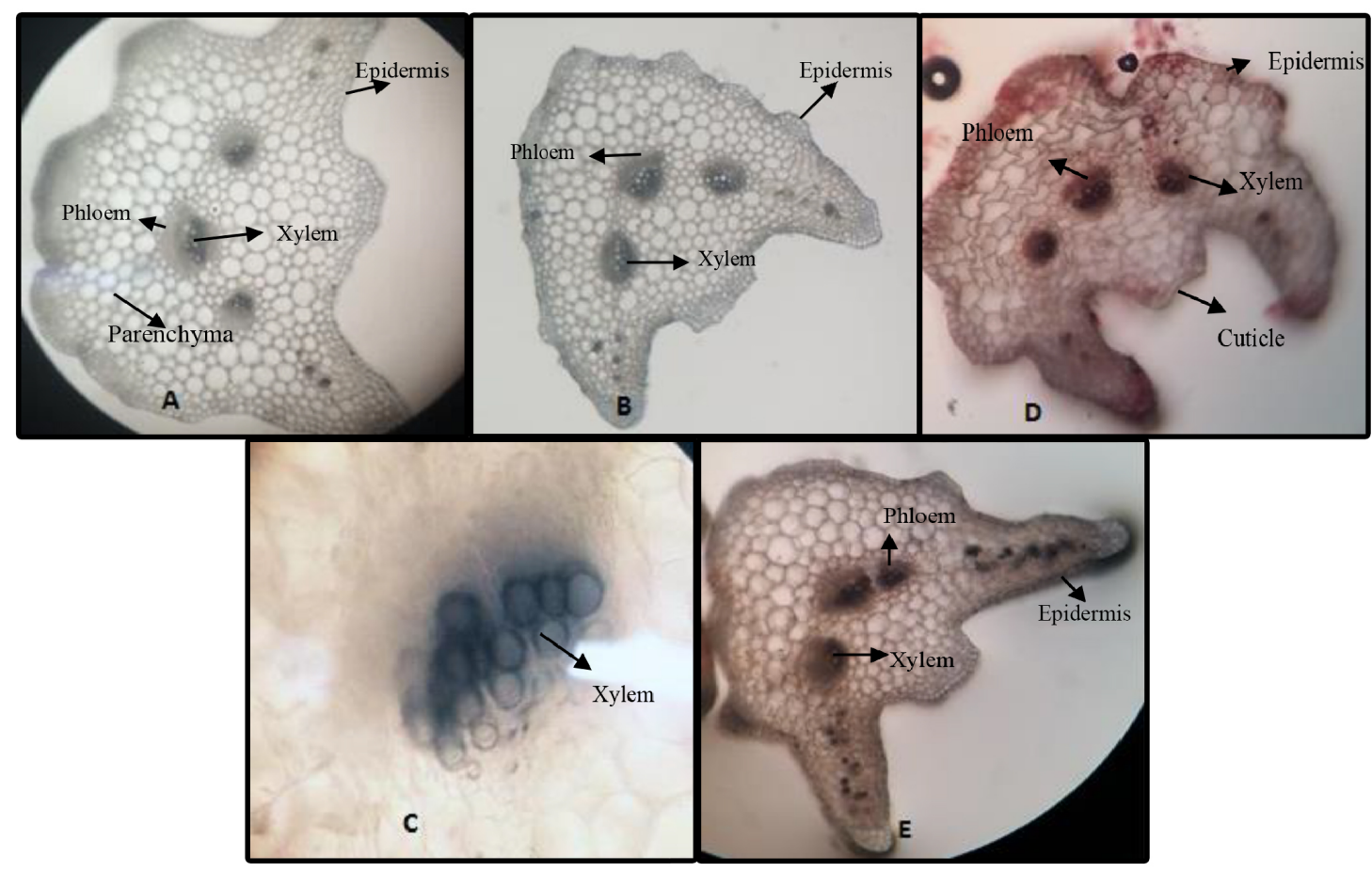

Figure 2. The effect of salinity on petiole anatomy of Beta vulgaris L. plants treated with various levels of salinity. A. control (×10), B. $100 \mathrm{mM} \mathrm{NaCl}(\times 10)$, C. $150 \mathrm{mM} \mathrm{NaCl}(\times 40)$, D. $200 \mathrm{mM} \mathrm{NaCl}(\times 10)$, E. $250 \mathrm{mM} \mathrm{NaCl}(\times 40)$. 
Plant roots are the first line of damage or defense due to the direct encounter with the saline soil solution (Rewald et al., 2012). Results of root anatomical studies showed that salinity had adverse effects on root anatomy of Beta vulgaris L. (Fig. 1). The increase in salinity resulted in a decrease in the phloem, xylem and cortical paranchyma thickness, protoxylem and metaxylem diameter, while epidermal layer thickness had reduction tendency from control to high $\mathrm{NaCl}$ concentration (200 and $250 \mathrm{mM}$ ) (Table 2, Fig. 1).

Anatomical modification of root was observed in Beta vulgaris plants treated with various levels of salinity. At higher saline condition $(250 \mathrm{~mm} \mathrm{NaCl})$ the epidermal thickness increaesed. In accordance with our study, the epidermal thickness was increased in Salvadora persica with increasing salinity (Parida et al., 2016). The salt stress induced increase in epidermal thickness of root reduces salt ion diffusion to the plant (Parida et al., 2016).

The diameter of root vascular bundles decreased as the external salinity increased. Xylems of plants encountering salinity tends to have vessels with lower diameter than unstressed groups (Junghans et al., 2006). Decreasing in the vessel diameter can be refered to reduce the hydraulic conductivity in the part formed during the stress period (Junghans et al., 2006). This modification in root xylem of the stressed plant confers safety to the vessel with significant conductivity (Junghans et al., 2006).

However, by reducing the vessel diameter of root, water uptake also reduced with the increase in the salinity consequently reduces photosynthesis (Junghans et al., 2006). Previous studies found smaller xylem vessels in stressed plants is in accordance with our results (Awasthi and Pathak, 1999; Boughalleb et al., 2009). Root parenchyma layer thickness was significantly affected by salinity (Table 2, Fig. 1). Parenchyma thickness was significantly decreased under salinity condition. Similar results were also presented by Akram et al., (2002), Hu et al., (2005) and Jafarian et al. (2012) on wheat. But in contrast with our results, Alshammary et al., (2004) and Parida et al. (2016), reported that with an increase in salinity there was an increase in parenchyma layer thickness.

On the contrary, cross-sectional thickness of the petiole epidermis, paranchyma, phloem, xylem and metaxylem \& protoxylem vessel diameter showed significant differences among all treatments (Table 3) decreasing from control to high $\mathrm{NaCl}$ concentration. In cross-section of control plants, the petioles are a semi-circular contour, with an adaxial ditch, with latero-adaxial wings with enhancing of salinity, petiole had tall big wings and compressed. These results are in agrement with finding of Poscher (2005) on Parthenium argentatum (Asteraceae). This is the first study about effect of salinity on petiole structure of Beta vulgaris; therefore, comparision with other researches was impossible.

The cuticle of Beta vulgaris was significantly denser in leaves treated with $\mathrm{NaCl}$ concentrations than the control (Table 4). Our observations were consistent with finding of Longstrethand and Nobel (1979) and Hajibagheri et al., (1982). In salt stressed plants, the leaf epidermis thickness was smaller than control; the salinity effect was concentration dependent. This decrease in epidermal thickness may be attributed to the limited cell division and growth at higher salinity (Carcamo et al., 2012). Our results showed a gradual decrease in thickness of mesophyll with increasing salinity. In accordance with our results there was a decrease in the mesophyll thickness with increasing salinity in semi-mangrove plant Myoporum botioides (Xu et al., 2014). The significant decrease in the palisade tissue at extreme salinity $(750 \mathrm{mM} \mathrm{NaCl})$ might be an adaptation of this halophyte to minimize the photosynthetic energy utilization in the higher saline condition (Parida et al., 2016).

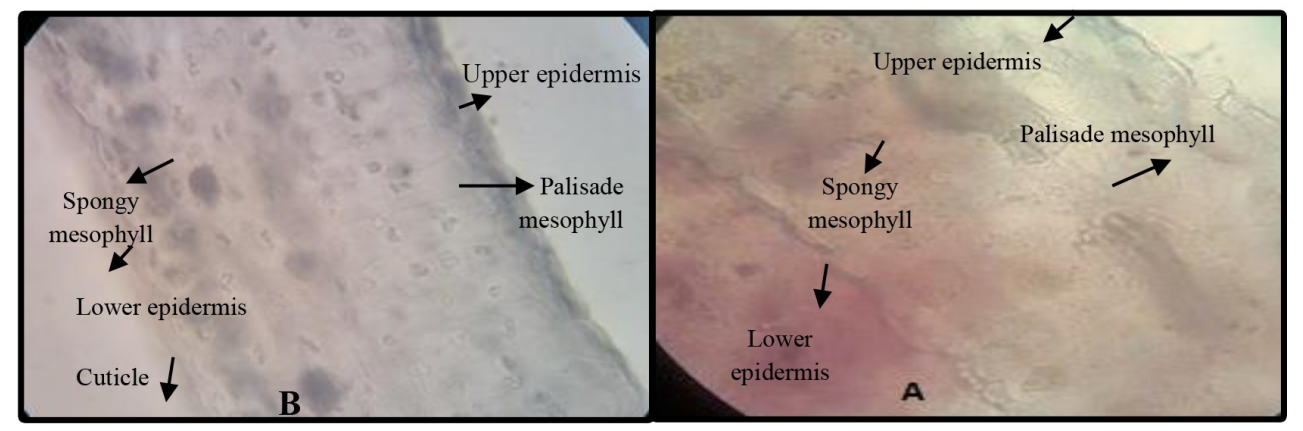

Figure 3. Effect of salinity on leaf anatomy of Beta vulgaris L. plants treated with various levels of salinity.A. $100 \mathrm{mM} \mathrm{NaCl}(\times 40)$, B. control $(\times 40)$. 


\section{Conclusion}

In conclusion, our results indicated that salt stress decreased Beta vulgaris seed germination \& early seedlimg growth and induced changes in anatomical characteristics such as increase of cutin synthesis on epidermal leaves cells and also changes in vascular system, epidermis, parenchyma in leaves, roots and petioles.

\section{ACKNOWLEDGEMENT}

We thank the referees for their comments on manuscript.

\section{REFERENCES}

Abdel-Monem, A.A., El-Bassiouny, H.M.S., Rady, M.M. \& Gaballah, M.S. 2010. The role of tryptophan and prozac (S-hydroxy tryptophan) on the growth, some biochemical aspects and yield of two sunflower cultivars grown in saline soil. International Journal of Academic Research 2: 225-231.

Abdul-Baki, B.A.A. \& Anderson, J.D. 1973. Relationship between decorboxylation of glutamic acid and vigor in soyabean seed. Crop Science 13: 227-234.

Akram, M., Akhtar, S., Javed, I.H., Wahid, A. \& Rasul, E. 2002. Anatomical attributes of different wheat (Triticum aestivum) accessions/varieties to $\mathrm{NaCl}$ salinity. International Journal of Agriculture and Biology 4: 166-168.

Alshammary, S.F., Qian, Y.L. \& Wallner, S.J. 2004. Growth response of four turf grass species. Agr. Water Management 66: 97-111.

An, P., Inanaga, S., Li, X., Schimizu, H. \& Tanimoto, E. 2003. Root characteristics in salt tolerance. Root Research 12: 125-132

Asadi Nasab, N., Hasibi, P. Roshanfekr, H. \& Meskarbashi, M. 2014. Study some physiological and morphological responses of three sugar beet cultivars to salinity stress. Journal of Crop Improvement 15: 74-91.

Ashraf, M. \& Rasul, E. 1988. Salt tolerance of mung bean at two growth stage. Plant and Soil 110: 63-67.

Ayaz, F.A., Kadioglu, A. \& Urgut, R.T. 2000. Water stess effects on the content of low molecular weight carbohydrates and phenolic acids in cienanthe setosa. Canadian Journal of Plant Science 80: 373-378

Awasthi, O.P. \& Pathak, R.K. 1999. Effect of salinity levels on survival and anatomy of four scion cultivars budded on Indian jujube. Horticulture Journal 12: 5359.

Bahrami, H. \& Razmjoo, J. 2012. Effect of salinity stress on germination and early seedling growth of ten sesame cultivars (Sesamum indicum L.). International Journal of Agricultural Science. 2: 529-537.

Bhattacharjee, S. 2008. Triadimefon pretreatment protects newly assembled membrane system and causes upregulation of stress proteins in salinity stressed Amaranthus lividus L. during early germination. Journal of Environmental Biology 29: 805-810.
Boughalleb, F., Hajlaoui, H. \& Denden, M. 2012. Effect of salt stress on growth, water relations, solute composition and photosynthetic capacity of herohalophyte Nitraria retusa (L.). Environmental Research 6: 1-13.

Boursiac, Y., Chen, S., Luu, D.T., Sorivul, M., Drias, N. \& Maural, C. 2005. Early effects of salinity on water transport Arabidopsis roots: Molecular and cellular features of aquaporin expression. Plant Physiology 139: 790-805.

Carcamo, H.J., Bustos, M.R., Fernandez, F.E. \& Bastias, E.I. 2012. Mitigating effect of salicylic acid in the anatomy of the leaf of Zea mays L. lluteno ecotype from the Lluta Valley (Arica-Chile) under $\mathrm{NaCl}$ stress. IDESIA (Chile) 30: 55-63.

Cavusoglu, K., Kılıc, S. \& Kabar, K. 2007. Some morphological and anatomical observations during alleviation of salinity $(\mathrm{NaCl})$ stress on seed germination and seedling growth of barley by polyamines. Acta Physiologiae Plantarum 29: 551557.

Ceccoli, G., Ramos, J. C, Ortega, L.I., Acosta, J.M. \& Perreta, M.G. 2011. Salinity induced anatomical and morphological changes in Chloris gayana Kunth roots. Biocell 35: 9-17.

Dadkhah, A. 2007. Effect of salinity on germination and seedling growth of four sugar beet genotypes (Beta vulgaris L.). Pajouhesh va Sazandegie 70: 88-93.

Datta, J.K., Banerjee, A. \& Mondal, N.K. 2009. Impact of salt stress on five varieties of wheat (Triticum aestivum L.) cultivars under laboratory condition. Journal of Applied Sciences and Environmental Management 13: 93-97.

Dolatabadian, A.S.A., Modarres, M. \& Sanavy Ghanati, F. 2011. Effect of salinity on growth, xylem structure and anatomical characteristics of soybean. Notulae Scientia Biologicae 3: 41-45.

El-Rodeney, W.M. \& El-Okkiah, S.A. 2012. Physiological and anatomical changes in Glycine max L. under salinity stress. Egypt. J. Bot. 2nd International conference, 29-30 April. Minia. Univ. pp. $37-50$.

El-Melegy, E.A., Gabr, M.F., Mohamed, H.F. \& Ismail, M.A. 2004. Responses to $\mathrm{NaCl}$ salinity of tomato cultivated and breeding lines differing in salt tolerance in callus cultures. International Journal of Agriculture and Biology 16: 19-26.

FAO. 2005. Global network on integrated soil management for sustainable use of salt affected soils, FAO Land and Plant Nutrient Management Service.

François, B.B. 2007. Effect of salinity on germination and seedling growth of canola (Brassica napus L.). The degree of Master of Agricultural Sciences at the University of Stellenbosch. Stellenbosch, South Africa.

Francois, L.E. 1984. Salinity effects on germination, growth and yield of turnips. Horticultural Science 19: 82-84.

Francois, L.E. 1985. Salinity effects on germination, growth and yield of two squash cultivars. Horticultural Science 20: 1102-1104. 
Gadalla, S.F. 2009. The role of antioxidants in inducing wheat flag leaf osmotic adjustment under salinity stress. Mansoura University. Journal of Agricultural Science 34: 10663-10685.

Ghoulam, C. \& Fares, K. 2001. Effect of salinity on seed germination and early seedling growth of sugar beet (Beta vulgaris L.). Seed Science and Technology 29: 357-364.

Gholizadeh, F., Manzari-Tavakkoli, A. \& Pazoki, A. 2016. Evaluation of Salt Tolerance on Germination Stage and Morphological Characteristics of Some Medicinal Plants Artichoke, Flax, Safflower and Coneflower. International Journal of Farming and Allied Sciences 5: 229-237.

Gulzar, S. \& Khan, M.A. 2001. Seed germination of a halophytic grass Aeluropus lagopoides. Ann. Bot. 87: 319-324.

Gulzar, S., Khan, M.A. \& Ungar, L.A. 2003. Salt tolerance of a coastal salt marsh grass. Communication in Soil Science and Plant Analysis 34: 2595-2605.

Gupta, R. \& Minhas, P.S. 1993. Managing salt affected waters for crop production. pp: 159-198. In: Singh S.D. (Ed.), Arid land irrigation and ecological management. Scientific Publishers, New Delhi.

Hadas, A. 1977. Water uptake and germination of leguminous seeds in soils of changing matrix and osmotic water potential. Journal of Experimental Botany 28: 977-985.

Hagghani, M., Saffari, M. \& Magsoudi-Moud, A.A. 2008. Effect of different levels of $\mathrm{NaCl}$ salinity on germination and seedling growth of safflower cultivars (Carthamus tinctorius L.). Journal of Agricultural Sciences and Natural Resources 45: 449458.

Hakim, M.A., Juraimi, A.S., Begum, M., Hanafi, M.M., Ismail, M.R. \& Selamat, A. 2010. Effect of salt stress on germination and early seedling growth of rice (Oryza sativa L.). African Journal of Biotechnology 19: 1911-1918.

Hasegawa, P.M. 2013. Sodium $\left(\mathrm{Na}^{+}\right)$homeostasis and salt tolerance of plants. Journal of Environmental and Experimental Botany 92: 19-31.

Hadas, A. 2004. Seed bed Preparation: The soil physical environment of germinating seeds. In Benech-Arnold, R. L. \& R. A. Sanchez (eds.) Handbook of Seed Physiology: Applications to Agriculture (pp. 480). New York: Food Product Press.

Hassan, A., Maher, S. \& Cherif, H. 2014. Effect of salt stress $(\mathrm{NaCl})$ on germination and early seedling parameters of three pepper cultivars (Capsicum annuum L.). Journal of Stress Physiology and Biochemistry 10: 14-25

Hussein, M.M., Abou Leila, B.H. \& Abdel-Hady, N.F. 2009. Influence of putrescine on growth of barley (Hordeurm vulgare L.) grown under salinity. Egypt. Agronomy Journal 31: 301-309.

Hussein, M.M., Abo-Leila, B.H., Metwally, S.A. \& Leithy, S.Z. 2012. Anatomical structure of Jatropha leaves affected by proline and salinity conditions. Journal of Applied Sciences Research 8: 491-496.
Hu, Y., Fromm, J. \& Schmidhalter, U. 2005. Effect of salinity on tissue architecture in expanding wheat leaves. Planta 220: 838-848.

Huang, J. \& Redman, R.E. 1995. Response of growth, morphology and anatomy to salinity and calcium supply in cultivated and wild barley. Canadian Journal of Botany 73: 1859-1866.

Jafarzadeh, A.A. \& Aliasgharzad, N. 2007. Salinity and salt composition effects on seed germination and root length of four sugarbeet cultivars. Bioclimatology and Natural Hazards. International Scientific Conference, Pol'ana nad Detvou, Slovakia.

Jafari, H.J., Azarnivand, H., Sadeghipour, A. \& Malekian, A. 2013. Effect of salinity stress on germination of Matricaria comomilla and Thymus deanensis. Desert 17: 305-307.

Jamil, M. \& Rha, E.S. 2004. The effect of salinity $(\mathrm{NaCl})$ on the germination and seeding of sugar beet (Beta vulgaris L.) and cabbage (Brassica oleracea L.). Korean. Journal of Plant Research 7: 226-232.

Junghans, U., Polle, A., Duchting, P., Weiller, E., Kuhlman, B., Gruber, F. \& Teichmann, T. 2006. Adaptation to high salinity in poplar involves changes in xylem anatomy and auxin physiology. Plant Cell Environment 29: 1519-1531.

Jamil, M.D., Bae Lee, K., Yong Jung, M., Ashraf, S.C., Lee, Y. \& Shik, R. 2006. Effect of salt $(\mathrm{NaCl})$ stress on germination and early seedling growth of four vegetabales species. Journal of Central European Agriculture 2: 273-282.

Jeannette, S., Craig, R. \& Lynch, J.P. 2002. Salinity tolerance of Phaseolus species during germination and early seedling growth Crop. Plant Science 42: $1584-1594$.

Kader, M.A. \& Jutzi, S.C. 2004. Effect of thermal and salt treatments during imbibition on germination and seedling growth of Sorghum at $42.19^{\circ} \mathrm{C}$. Journal of Agronomy and Crop Science 190: 35-38.

Kamali, N., Sadeghipour, A. \& Azarnivand, H. 2011. Effect of salinity on germination characteristics of Prosopis spicigera and P. juliflora. GIAN, 25-26 September, University of Tehran, pp.41-45.

Katembe, W.J., Ungar, I.A. \& Mitcell, Y.P. 1998. Effect of salinity on germination and seedling growth of two Atriplex species (Chenopodiaceae). Annals of Botany 82: 167-175.

Kandil, A.A., Sharrief, A.E. \& Ahmed, S.R.H. 2012.Germination and seedling growth of some chickpea cultivars (Cicer arietinum L.) under salinity stress. Journal of Basic Applied Scientific Research 8:501-541.

Khajeh, M., Powell, A.A. \& Bingham, I.J. 2003. The interaction between salinity stress and seed vigour during germination of soybean seeds. Seed Science and Technology 31: 715-725.

Khan, M.A., Gul, B. \& Weber, D.J. 2002. Seed germination in the great Basin halophyte Salsola iberica. Journal of Arid Environments 4: 231-244.

Khayamim, S., Tavakkol Afshari, R., Sadeghian, S.Y., Poustini, K., Rouzbeh, F. \& Abbasi, Z. 2014. Seed Germination, plant establishment, and yield of sugar 
beet genotypes under salinity stress. Journal of Agricultural Science and Technology 16: 779-790.

Kılıç, S., Çavuşoğlu, K. \& Kabar, K. 2007. Effects of 24- epibrassinolide on salinity stress induced inhibition of seed germination, seedling growth and leaf anatomy of barley. Süleyman Demirel University Faculty of Arts and Science

Journal of Science 2: 41-52.

Khodarahmpour, Z., Ifar, M. \& Motamedi, M. 2012. Effects of $\mathrm{NaCl}$ salinity on maize (Zea mays L.) at germination and early seedling stage. African Journal of Biotechnology 11: 298-304.

Longstreth, D.J. \& Nobel P.S. 1979. Salinity effects on leaf anatomy, consequences for photosynthesis. Plant Physiology 63: 700-703.

Mohammadian, R. 1995. Effect of seeds depreciation on germination, growing and settlement of seven sugar beet cultivars under salinity stress. MSc Thesis. Faculty of Agriculture, Tabriz University, Tabriz, Iran.

Mauromicale, G. \& Licandro, P. 2002. Salinity and temperature effects on germination, emergence and seedling growth on globe artichoke. Agronomic. 22: 443-450

Mensuh, J.K., Akomeah, P.A., Ikhajiagbe, B. \& Ekpekurede, E.O. 2006. Effects of salinity on germination, growth and yield of five groundnut genotypes. African Journal of Biotechnology 5: 19731979.

Mori, M., Di-Mola, I. \& Quaglietta-Chiaranda, F. 2011. Salt stress and transplant time in snap bean: growth and productive behavior. International Journal of Plant Production 5: 49-63.

Mostafavi, K \& Hydaryan, A.R. 2013. Effects of salinity different levels on germination indices in four varieties of sunflower (Helianthus annuus L.). Journal of Basic and Applied Science 3: 2043-2051.

Mostafavi, K., Sadeghi Geive, H., Dadresan, M. \& Zarabi, M, 2011. Effects of drought stress on germination indices of corn hybrids (Zea mays L.). International Journal of Agricultural Science 1: 10-18.

Munns, R. \& Termaat, A. 1986. Whole-plant responses to salinity. Australian Journal of Plant Physiology 13: 143-160.

Osorio, J., Osorio, M.L., Chaves, M.M. \& Pereira, J.S. 1998. Tree Physiology 18: 363-373.

Parida, A.K., Veerabathin, S.K., Kumari, A. \& Agarwal, K. 2016. Physiological, anatomical and metabolic implications of salt tolerance in halophytic Salvadora persica under hydroponic culture condition. Front. Plant Science 7: 1-18.

Panuccio, M.R., Jacobsen, S.E., Akhtar, S.S. \& Muscolo, A. 2014. Effect of saline water on seed germination and early seedling growth of the halophyte Quinoa. Annals of Botany 6: 1-18.

Poscher, E. 2005. Salinity effects on Guayule leaf anatomy and physiology. Faculty of Office Arid Lands Studies. Degree of Doctor of Philosophy, The University of Arizona.

Rehman, S., Harris, P.J.C., Bourne, W.F. \& Wilkin, J. 1996. The effect of sodium chloride on germination and the potassium and calcium content of Acacis seeds. Seed Science Technology 25: 45-57.

Price, A. \& Hendry, G. 1991. Iron catalyzed oxygen radical formation and its possible contribution to drought damage in nine native grasses and three cereals. Plant Cell Environment 14: 477-484.

Rahman, M., Kayani, S.A. \& Gul, S. 2000. Combined effects of temperature and salinity stress on corn cv. Sunahry. Pakistan Journal of Biological Science 3: 1459- 1463.

Rahman, M., Soomro UA, Haq M.Z. \& Gul, S. 2008. Effects of $\mathrm{NaCl}$ salinity on wheat (Triticum aestivum L.) cultivars. World Journal of Agricultural Sciences 4: 398-403.

Rehman, S., Harris, P.J.C., Bourne, W.F. \& Wilkin, J. 1996. The effect of sodium chloride on germination and the potassium and calcium content of Accacia seeds. Seeds Science and Technology 25: 41-57.

Redmann, R.E., Belyk, M. \& MQ, Qi. 1994. Growth of transgenic and standard canola (Brassica napus) varieties in response to soil salinity. Canadian Journal of Plant Science 74: 797-799.

Redondo-Gómez, S., Mateos-Naranjo, E., Davy, A.J., Fernández-Muñoz, F., Castellanos, E.M., Luque, T. \& Figueroa, M.E. 2007. Growth and photosynthetic responses to salinity of the salt-marsh shrub Atriplex portulacoides. Annals of Botany 100: 555-563.

Roberts, E.H. \& Osei-Bonsu, K. 1988. Seed and seedling vigour. pp. 897-910. In: Summerfield, R.J. (ed.), World crop: Cool Season Food Legumes.

Saffan, S.E. 2008. Effect of salinity and osmotic stress in some economic plants. Research Journal of Agricultura and Biological Sciences 4: 159-166.

Shahriary, E. 2003. Effect of salinity stress on germination and growth of two Atriplex species. MSc Thesis, University of Tehran, $191 \mathrm{pp}$.

Sairam, R.K. Tyagi, A. 2004. Physiology and molecular biology of salinity stress tolerance in plants. Current Science 86: 407-721.

Sativa, K. \& Jakhar, S. 2015. Effect of pre-treatment of chickpea (Cicer arietinum L.) seeds on seed germination and seedling growth under salt stress. International Journal of Advanced Research 3: 303311.

Serrano, R., Mulet, J.M., Rios, G., Marquez, J.A. \& de Larrinoa, I.F. 1999. A glimpse of the mechanism of ion homeostasis during salt stress. Journal of Experimental Botany 50: 1023-1036.

Sozharajan, R. \& Natarajan, S. 2014. Germination and seedling growth of Zea mays L. under different levels of sodium chloride stress. International Letters of natural Sciences 12: 5-15.

Vijayan, K., Chakraborti, S.P., Ercisli, S. \& Ghosh, P.D. 2008. $\mathrm{NaCl}$ induced morpho-biochemical and anatomical changes in mulberry (Morus spp.). Plant Growth Regulation 56: 61-69.

Werner, J.E. \& Finkelstein, R.R. 1995. Arabidopsis on growth of roots and shoots in soybean. Plant mutants with reduced response to $\mathrm{NaCl}$ and osmotic stress. Physiologia Plantarum 93: 659-666. 
Yavari, N. Mesbah, M. \& Ghaffari Jahromi, A. 2005. A study on advancing treatment on Sugar Beet embryo culture in salt stress conditions in vitro. Journal Sugar Beet 21: 87-97.

Yildirim, E., Turan, M. \& Guvenc, I. 2008. Effect of foliar salicylic acid applications on growth, chlorophyll and mineral content of cucumber grown under salt stress. Journal of Plant Nutrition 31: 59

Younis, A., Riaz, A., Ahmed, I. \& Nadeem, A. 2014. Anatomical changes induced by $\mathrm{NaCl}$ stress in root and stem of Gazania harlequin L. Agricultural Communication 2: 8-14.

Yousefinia, M., Ghassemian, A., Sofalian, O. \& Khomari, S. 2012. Effects of salinity stress on barley (Hordeum vulgare L.) germination and seedling growth. International Journal of Agriculture and Crop Science 4: 1353-1357.

Xiong, L. \& Zhu, J.K. 2002. Molecular and genetic aspects of plant responses to osmotic stress. Plant Cell Environment 25:131-139
Xu, H.M., Tam, N.F., Zan, Q.J., Bai, M. Shin, P.K.S. \& Vrijmoed, L.L.P. 2014. Effects of salinity on anatomical features and physiology of a semimangrove plant Myoporum bontioides. Marrine Pollution Bulletin 85: 738-746.

Zakery-Asl, M.A., Bolandnazar, S. \& Oustan, S. 2014. Effect of salinity and nitrogen on growth, sodium, potassium accumulation, and osmotic adjustment of halophyte Suaeda aegyptica (Hasselq.) Zoh. Archives Agronomy and Soil Science 60: 785-792.

Zeinali, A. \& Soltani, A. 2002. Components in canola seed germination response to salt stress. The Journal of Agricultural Science 33: 137-145.

Zhu, J.K. 2001. Over expression of a delta-pyrroline-5carboxylate synthetase gene and analysis of tolerance to water and salt stress in transgenic rice. Trends in Plant Science 6: 66- 67.

Zhu, J.K., Hasegawa, P.M. \& Bressan, R.A. 1997. Molecular aspects of osmotic stress in plants. Critical Reviews in Plant Science 16: 253-277.

How to cite this article:

Nejadhabibvash, F. \& Mohammad Bagher Rezaee, M.B. 2021. The effect of salinity on seed germination, early seedling growth and anatomical structure of Beta vulgaris. Nova Biologica Reperta 7: 419-430. 